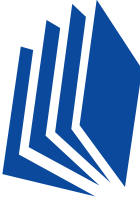

INNSPUB

\section{International Journal of Biosciences | IJB | \\ ISSN: 2220-6655 (Print), 2222-5234 (Online) \\ http://www.innspub.net}

Vol. 12, No. 1, p. 111-118, 2018

RESEARCH PAPER

OPEN ACCESS

\title{
Antifungal activity of Vanillin, Benzophenone, Acetophenone Thiosemicarbazones and their Cobalt (II) and Nickel (II)
} complexes

\author{
Sha Md. Shahan Shahriar*, Hossain Mohammad Zakir, Mele Jesmin, \\ Shaikh Mohammad Mohsin Ali \\ Department of Applied Chemistry and Chemical Engineering, Rajshahi University, \\ Rajshahi, Bangladesh
}

Key words: Antifungal activity, Minimal fungicidal concentration, Schiff bases, Schiff base complexes

http://dx.doi.org/10.12692/ijb/12.1.111-118 $\quad$ Article published on January 12, 2018

\begin{abstract}
Since the prehistoric times fungal infections are one of the most common diseases known to humanity and mortality due to these infections even with antifungal therapy is still unacceptably high. Therefore, the development of new antifungal agents targeting specific fungal structures or functions is being actively pursued. The antifungal activity of three schiff bases (vanillin thiosemicarbazone, benzophenone thiosemicarbazone and acetophenone thiosemicarbazone) and two schiff base complexes vanillin thiosemicarbazone with $\mathrm{Ni}(\mathrm{II})$ and $\mathrm{Co}(\mathrm{II})$ were studied against some fungus (Candida albicans, Aspergillus niger, Aspergillus flavus, Aspergillus fumigates and Mucor sp.) by disc diffusion method. The antifungal activity was compared with the standard drug nystatin. Both schiff bases and schiff base complexes showed significant antifungal activity against all test organisms. But among all the experimental compounds the activity of vanillin thiosemicarbazone with $\mathrm{Ni}$ (II) against all test organisms was quite comparable with that of standard drug nystatin at dose $100 \mu \mathrm{g} /$ disc. Other four compounds vanillin thiosemicarbazone, benzophenone thiosemicarbazone, acetophenone thiosemicarbazone and vanillin thiosemicarbazone with Co (II) showed moderate activity. Among all schiff bases, VTS showed highest zone of inhibition $(27 \pm 1.2 \mathrm{~mm})$ against Candida albicans at dose $200 \mu \mathrm{g} /$ disc. For schiff base complexes, the

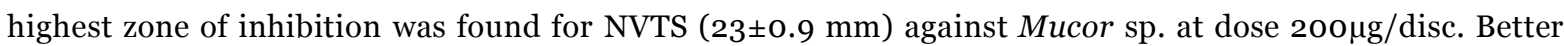
results were obtained with high doses. All these synthesized compounds were found to possess cytotoxic effect. Minimal fungicidal concentration of these compounds was also determined. It is concluded that these compounds are biologically active and can be primarily considered as potent antifungal agents.
\end{abstract}

*Corresponding Author: Sha Md. Shahan Shahriar $\bowtie$ shahan.acrubd@gmail.com 


\section{Introduction}

Schiff bases and their metal complexes have gained importance in medicinal and pharmaceutical fields due to a broad spectrum of biological activities like antiinflammatory (Sathe et al., 2011; Ali et al., 2012; Chandramouli et al., 2012), analgesic (Chinnasamy et al., 2010; Ali et al., 2012; Chandramouli et al., 2012), antimicrobial (Venkatesh, 2011; Islam et al., 2013), anticonvulsant (Chaubey and Pandeya, 2012), antitubercular (Cimerman et al., 2000; Aboul-Fadl et al., 2003), anticancer (Ali et al., 2012; Miri et al., 2013), antioxidant (Schiff, 1864; Wei et al., 2006), anthelmintic (Avaji, 2009), and so forth. The nitrogen atom of azomethine may be involved in the formation of a hydrogen bond with the active centers of cell constituents and interferes in normal cell processes (Venugopala and Jayashree, 2003; Vashi and Naik, 2004). Schiff bases derived from isatin derivatives and $\mathrm{N}[4-(4$ '-chlorophenyl) thiozole-2-yl] thiosemicarbazide, have already proved to be potent antimicrobial agents (Pandeya et al., 1999). The synthesis and characterization of a number of new schiff bases derived from metronidazole have been undertaken and their antigiardial and antimicrobial activities were evaluated (Sadeh et al., 2011). Metalbased drugs represent a novel group of antifungal agents with potential applications for the control of fungal infections. This inspires synthetic chemists to search for new metal complexes for bioactive compounds. The field of macrocylic chemistry of metals is developing very rapidly because of its applications and importance in the area of coordination chemistry (Chaudhary et al., 2003). In the present paper, the antifungal activity of three schiff bases namely vanillin thiosemicarbazone (VTS), benzophenone thiosemicarbazone (BTS), acetophenone thiosemicarbazone (ATS) and two schiff base complexes namely vanillin thiosemicarbazone with Ni (II)-(NVTS) and vanillin thiosemicarbazone with Co (II)-(CVTS) have been studied.

\section{Materials and methods}

Chemicals

All chemicals and reagents used to carry out the research work were of reagent grade and purchased from BDH (England). All chemicals and reagents were used without further purification.
Synthesis of the compounds

The schiff bases were synthesized by the method in the same way as described in literature (Quraishi et al., 2002; Glinma et al., 2011). The schiff bases were verified by taking melting points (Barton and Ollis, 1979; Quraishi et al., 2002; Glinma et al., 2011), elemental analysis and conducting infrared spectral (IR) studies (as KBr disc by a Shimadzu FTIR, Japan). The new bond $>\mathrm{C}=\mathrm{N}$ - (azomethine) formed during the synthesis in all the cases was confirmed from IR spectrum of $>\mathrm{C}=\mathrm{N}$ - bond at around $1630 \mathrm{~cm}^{-1}$ which was in this accordance with the literature (Barton and Ollis, 1979). The characteristics data of the synthesized schiff bases are given in the Table 1. The schiff base complexes were synthesized according to previously described method (Aravindakshan and Nair, 1984).

The formation of the synthesized schiff base complexes were verified by measuring melting points and conducting infrared spectral studies (Aravindakshan and Nair, 1984). The disappearance of peaks at $775 \mathrm{~cm}^{-1}$ (for $\gamma \mathrm{c}=\mathrm{s}$ ) and appearance at 660 $\mathrm{cm}^{-1}$ (for $\gamma \mathrm{c}-\mathrm{s}$ ) confirmed the formation of $\mathrm{M}-\mathrm{S}$ bond in the complexes. Furthermore, the appearance of peak at $550 \mathrm{~cm}^{-1}$ in both the complexes might be related to M-N where $\mathrm{M}$ stand for metal viz. Co (II) or $\mathrm{Ni}(\mathrm{II})$, which is given bellow. The shifting of the peak for $\mathrm{C}=\mathrm{N}\left(\right.$ at $\left.1620 \mathrm{~cm}^{-1}\right)$ to a lower wave number $(\sim$ $1580 \mathrm{~cm}^{-1}$ ) supported the participation of $\mathrm{N}$ (of the ligand) in the complex formation. The characteristics data of the synthesized schiff base complexes are given in the Table 2.

The structures of synthesized compounds are shown below:

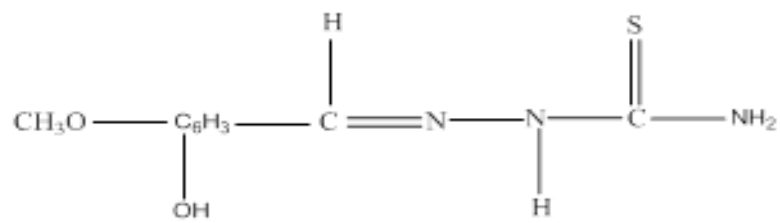

Vanillin thiosemicarbazone (VTS) 


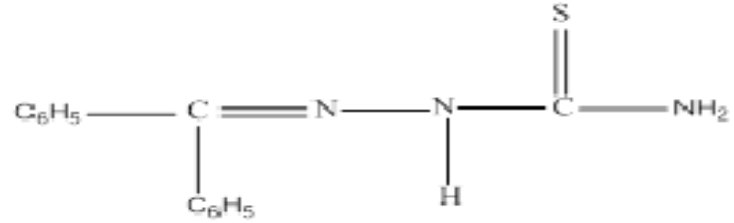

Benzophenone thiosemicarbazone (BTS)

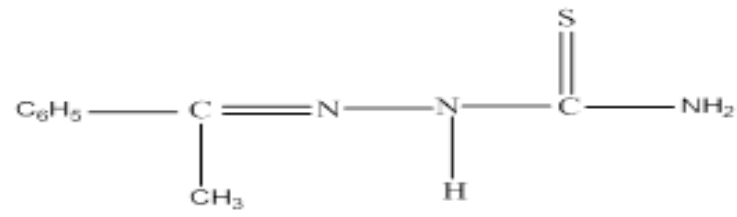

Acetophenone thiosemicarbazone (ATS)

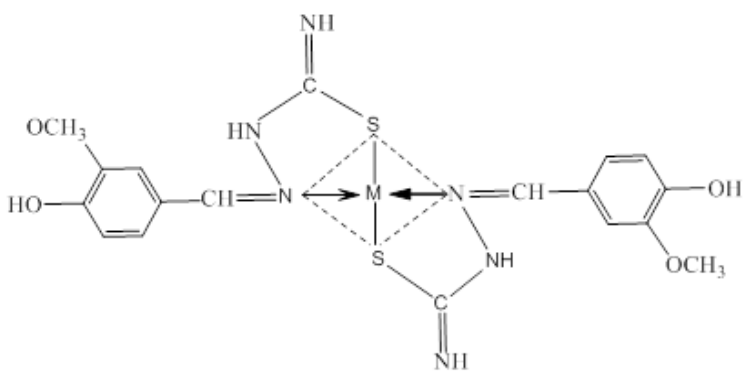

Square planar structure of the complex where $\mathrm{M}$ stands for $\mathrm{Co} / \mathrm{Ni}$

\section{Antifungal activity test}

Antifungal activity was performed by disc diffusion assay method (Srivastava, 1984). Nystatin $(100 \mu \mathrm{g} / \mathrm{disc})$ was used as standard.

\section{Test organisms}

For antifungal activity test, five experimental fungi (Candida albicans, Aspergillus niger, Aspergillus flavus, Aspergillus fumigates and Mucor sp.) were collected from the Institute of Biological Science, University of Rajshahi, Bangladesh.

\section{Preparation of the media}

Potato dextrose agar (PDA) media was used to perform the antifungal activity test and for subculture of the test organisms. Accurately weighed $20.0 \mathrm{~g}$ potato, 2.o g dextrose and $2 \mathrm{~g}$ agar were dispersed in a conical flask with $100 \mathrm{ml}$ distilled water. It was heated in a water bath to dissolve the ingredients until a transparent solution was obtained. The $\mathrm{pH}$ of the media was adjusted to 5.6. The volume was adjusted by adding distilled water and sterilized in an autoclave.

\section{Preparation of inoculum}

The spore of isolated pure fungi were inoculated in screw capped tube containing equal amount of PDA media and incubated at $28^{\circ} \mathrm{C}$ for 5-7 days for the development of new pure culture that was used as inoculum.

\section{Preparation of test sample}

Sample solutions of VTS, BTS, ATS, NVTS and CVTS at concentration of $100 \mu \mathrm{g} /$ disc and $200 \mu \mathrm{g} /$ disc were prepared separately (by dissolving 10mg and 20mg in $1 \mathrm{~mL}$ DMSO of each test compound). Desired amounts of the sample solutions were applied on the discs with the help of a micropipette in an aseptic condition. The discs were left for a few minutes in the same condition for complete removal of solvents.

\section{Procedure}

Distilled water (10mL) was poured in several clean test tubes and plugged with cotton. The test tubes, petridishes, glass rods, cottons and the media were sterilized by autoclave and then transferred to the laminar air flow cabinet. Media $(6 \mathrm{~mL})$ was poured carefully in the medium sized petridishes in each. The petridishes were rotated several times, first clockwise and then anticlockwise for homogenous thickness. Then the media was allowed to cool and solidified at about $30^{\circ} \mathrm{C}$.The test tubes containing distilled water were inoculated with fresh culture of the test fungi and shaken gently to form a uniform suspension of the organisms because of their high prevalence sporulation process. A piece of cotton was immerged in the test tubes with the help of individual glass rod and then gently rubbed with the media. The cotton was then discarded. Finally, the plates were stored in a refrigerator $\left(4^{\circ} \mathrm{C}\right)$ for overnight. Preparation and placement of the discs, diffusion, incubation and measurement of zone of inhibition were almost the same as those of the antibacterial screening. The incubation period was adjusted for 48-72 hours at room temperature.

\section{Minimum fungicidal concentration (MFC)}

The Minimal Fungicidal Concentration (MFC) is defined as the lowest concentration of the compounds that is required to kill a particular fungal species.

\section{Shahriar et al.}


The in vitro $\mathrm{MFC}$ was determined as described in the literature (Espinel-Ingroff et al., 2002). After 72 h of incubation, $20 \mu \mathrm{L}$ was subcultured from each well that showed no visible growth (growth inhibition of over 98\%), from the last positive well (growth similar to that for the growth control well), and from the growth control (extract-free medium) onto PDA media. The media were incubated at $27{ }^{\circ} \mathrm{C}$ until growth was seen in the growth control subculture. The minimum fungicidal concentration was regarded as the lowest extract concentration that did not yield any fungal growth on the solid medium used.

\section{Statistical analysis}

The experimental results have been expressed as the mean \pm S.E.M. Data have been calculated by one way ANOVA followed by Dunnett " $\mathrm{t}$ " test using SPSS software of 16 version.

\section{Results and discussion}

The results for antifungal activity of these schiff bases and schiff base complexes are shown in Table 3 and 4 respectively. The antifungal activity was compared with the standard drug nystatin. Both schiff bases and schiff base complexes showed significant antifungal activities against all test organisms. Better results were obtained with high doses.

Table 1. Characteristics data of the synthesized schiff bases.

\begin{tabular}{|c|c|c|c|c|c|c|}
\hline \multirow{2}{*}{$\begin{array}{l}\text { Synthesize } \\
\text { d } \\
\text { compounds }\end{array}$} & \multicolumn{6}{|c|}{ Characteristics } \\
\hline & \% Yield & Physical form & Color & Solubility & Melting point & IR spectra, $\mathrm{cm}^{-1}$ \\
\hline VTS & 83 & Crystalline & White & $\begin{array}{l}\text { DMSO, Ethanol, } \\
\text { Methanol. }\end{array}$ & $136-138$ & $\begin{array}{l}\text { 1630sh }(>\mathrm{C}=\mathrm{N}-) \\
1586 \mathrm{~s}\left(\mathrm{C}_{6} \mathrm{H}_{5}\right) \\
775 \mathrm{w}(\mathrm{C}=\mathrm{S}) \\
2840 \mathrm{os}\left(\mathrm{OCH}_{3}\right) \\
\text { 3530s }(\text { phenolic-OH) } \\
3156 \mathrm{~s}\left(\mathrm{NH}_{2}\right)\end{array}$ \\
\hline$\overline{\text { BTS }}$ & 76 & Crystalline & White & $\begin{array}{c}\text { DMSO, Ethanol, } \\
\text { Methanol. }\end{array}$ & $169-170$ & $\begin{array}{l}1625 \mathrm{w}(>\mathrm{C}=\mathrm{N}-) \\
1532 \mathrm{~s}, 3182-3070 \mathrm{~W}\left(\mathrm{C}_{6} \mathrm{H}_{5}\right) \\
775 \mathrm{~s}(>\mathrm{C}=\mathrm{S}) \\
3200 \mathrm{w}\left(\mathrm{NH}_{2}\right)\end{array}$ \\
\hline ATS & 86 & Crystalline & White & $\begin{array}{l}\text { DMSO, Ethanol, } \\
\text { Methanol. }\end{array}$ & $114-116$ & $\begin{array}{l}1620 \mathrm{os}(>\mathrm{C}=\mathrm{N}-) \\
1570 \mathrm{O}\left(\mathrm{C}_{6} \mathrm{H}_{5}\right) \\
775 \mathrm{~s}(>\mathrm{C}=\mathrm{S}) \\
3200 \mathrm{~W}\left(\mathrm{NH}_{2}\right)\end{array}$ \\
\hline
\end{tabular}

The activity of NVTS against all test organisms was quite comparable with that of standard drug nystatin at dose $100 \mu \mathrm{g} /$ disc. Other four compounds (VTS, BTS, ATS and CVTS) showed moderate activity. The solvent DMSO showed no activity against any fungal strain. MFC values of the synthesized compounds were determined as $\mu \mathrm{g} / \mathrm{mL}$ and are shown in Table 5. Antifungal activity was studied of two schiff bases derived from glycylglycine with imidazole-2carboxaldehyde and indole-3-carboxaldehyde and their complexes with Zn (II) (Joseyphus and Nair, 2008).

Table 2. Characteristics data of the synthesized schiff base complexes.

\begin{tabular}{|c|c|c|c|c|c|c|}
\hline \multirow{2}{*}{$\begin{array}{l}\text { Synthesized } \\
\text { compounds }\end{array}$} & \multicolumn{6}{|c|}{ Characteristics } \\
\hline & \% Yield & Physical form & Color & Solubility & Melting point ${ }^{\circ} \mathrm{C}$ & IR spectra $\mathrm{cm}^{-1}$ \\
\hline NVTS & 49 & Crystalline & Grey & DMSO, Ethanol, Methanol. & $236-240$ & $\begin{array}{l}\text { 3150m (-OH), } \\
1598 \mathrm{~s}(>\mathrm{C}=\mathrm{N}), 66 \mathrm{om} \\
(\mathrm{C}-\mathrm{S}), 555 \mathrm{~m}(\mathrm{Ni}-\mathrm{N}), \\
35 \mathrm{Om}(\mathrm{Ni}-\mathrm{S})\end{array}$ \\
\hline CVTS & 46 & Crystalline & Black & DMSO, Ethanol, Methanol. & More than 250 & $\begin{array}{l}\text { 3150m }(-\mathrm{OH}), \\
1595 \mathrm{~s}(>\mathrm{C}=\mathrm{N}), 66 \mathrm{om}(\mathrm{C}- \\
\mathrm{S}), 550 \mathrm{~m}(\mathrm{Co}-\mathrm{N}), \\
348 \mathrm{~m}(\mathrm{Co}-\mathrm{S})\end{array}$ \\
\hline
\end{tabular}


They found the schiff base ligands and their complexes indicates that the complexes exhibit higher antifungal activity than the free ligands. It was found that the antifungal activity of schiff base derived from glycine using 2,3-butanedione, 5-methyl-2,6pyrimidine-dione and its metal complexes with $\mathrm{Cu}(\mathrm{II}), \mathrm{Ni}(\mathrm{II}), \mathrm{Co}(\mathrm{II})$ and $\mathrm{Zn}(\mathrm{II})$ (Srivastva et al., 2016).

Table 3. Antifungal activity of the schiff bases.

\begin{tabular}{|c|c|c|c|c|c|c|c|}
\hline \multirow[t]{2}{*}{ Test organisms } & \multicolumn{2}{|c|}{ VTS $(\mu \mathrm{g} /$ disc $)$} & \multicolumn{2}{|c|}{ BTS $(\mu \mathrm{g} /$ disc $)$} & \multicolumn{2}{|c|}{$\operatorname{ATS}(\mu \mathrm{g} /$ disc $)$} & \multirow{2}{*}{$\frac{\text { Nystatin }(\mu \mathrm{g} / \text { disc })}{100}$} \\
\hline & 100 & 200 & 100 & 200 & 100 & 200 & \\
\hline \multicolumn{8}{|c|}{ Diameter of zone of inhibition (in mm) } \\
\hline Aspergillus flavus & $15 \pm 0.6$ & $17 \pm 0.5$ & $14 \pm 0.4$ & $15 \pm 0.6$ & $\mathrm{R}$ & $11 \pm 0.4$ & 24 \\
\hline Aspergillus fumigatus & $\mathrm{R}$ & $\mathrm{R}$ & $15 \pm 0.5$ & $17 \pm 0.8$ & $18 \pm 0.4$ & $22 \pm 1.1$ & $22 \pm 0.4$ \\
\hline Aspergillus niger & $\mathrm{R}$ & $12 \pm 0.5$ & $15 \pm 0.8$ & $17 \pm 0.8$ & $17 \pm 0.8$ & $21 \pm 0.8$ & $25 \pm 0.5$ \\
\hline Candida albicans & $22 \pm 1.0$ & $27 \pm 1.2$ & $14 \pm 0.8$ & $18 \pm 0.7$ & $8 \pm 1.2$ & $12 \pm 1.3$ & $31 \pm 0.8$ \\
\hline Mucor sp. & $19 \pm 0.6$ & $24 \pm 0.6$ & $18 \pm 0.8$ & $23 \pm 1.1$ & $10 \pm 1.0$ & $13 \pm 1.0$ & $29 \pm 0.4$ \\
\hline
\end{tabular}

$\mathrm{R}=$ Resistance.

They found that both schiff base and metal complexes possess antifungal activity and metal complexes exhibit more activity than free schiff base against fungi. Schiff base complexes of Mn (II), Co (II), Ni (II), Cu (II), Zn (II), Cd (II), Hg (II) and Tin (II) with 3-methyl-2-(pyridine-2-yl-methylene hydrazinocarbonyl)quinoxaline-4-oxide and 2-(2hydroxy benzylidene-hydrazinocarbonyl)-3methylquinoxaline-4-oxide were prepared and antifungal activity was studied (Mahal et al., 2015). They investigated that the antifungal activity was enhanced by chelation.

Table 4. Antifungal activity of the schiff base complexes.

\begin{tabular}{lccccc}
\hline Test organisms & \multicolumn{2}{c}{ NVTS $(\mu \mathrm{g} /$ disc $)$} & \multicolumn{2}{c}{ CVTS $(\mu \mathrm{g} /$ disc) } & Nystatin $(\mu \mathrm{g} /$ disc $)$ \\
\cline { 2 - 6 } & 100 & 200 & 100 & 200 & 100 \\
\hline Diameter of zone of inhibition (in $\mathrm{mm})$ & & & & & \\
\hline Aspergillus flavus & $12 \pm 0.8$ & $17 \pm 1.0$ & $13 \pm 0.6$ & $\mathrm{R}$ & 24 \\
\hline Aspergillus fumigatus & $14 \pm 0.6$ & $\mathrm{R}$ & $15 \pm 1.1$ & $\mathrm{R}$ & $22 \pm 0.4$ \\
\hline Aspergillus niger & $15 \pm 0.8$ & $19 \pm 1.2$ & $09 \pm 0.5$ & $14 \pm 0.8$ & $25 \pm 0.5$ \\
\hline Candida albicans & $20 \pm 1.1$ & $\mathrm{R}$ & $11 \pm 0.6$ & $17 \pm 0.8$ & $31 \pm 0.8$ \\
\hline Mucor sp. & $14 \pm 0.7$ & $23 \pm 0.9$ & $15 \pm 1.0$ & $\mathrm{R}$ & $29 \pm 0.4$ \\
\hline
\end{tabular}

$\mathrm{R}=$ Resistance.

The $\mathrm{Cu}(\mathrm{II})$ complexes has the highest inhibition zone against $A$. niger. Six schiff bases were prepared by reacting 3,3'-diaminodipropylamine with different benzaldehyde derivatives and their antifungal activity was studied. It was found that, these compounds showed antifungal activity and considered as a promising and potential antifungal agent (Matar et al., 2015).

The mode of action of these compounds should be done to elucidate the structure-function relationship.
Based on previously published study of some schiff base complexes (Joseyphus and Nair, 2008), it was suggested that the mode of action may involve various targets in microorganisms.

These mechanisms can be classified into four points: (1) the interference with the cell wall synthesis as a result the cell permeability may be altered or they may disorganize the lipoproteins leading to cell death, (2) Deactivate various cellular enzymes which are important in the microorganism's metabolic 
pathways, (3) Formation of a hydrogen bond through the azomethine group with the active centres of cell constituents resulting in interfering with the normal cell processes, (4) Denaturation of one or more proteins of the cell, as a result of which the normal cellular processes are impaired. Finally, from the results discussed above it is clear that the synthesized schiff bases and schiff base complexes are biologically active.

Table 5. Minimal Fungicidal Concentration (MFC) of schiff bases and schiff base complexes.

\begin{tabular}{lccccc}
\hline Test organisms & $\begin{array}{c}\text { VTS } \\
(\mu \mathrm{g} / \mathrm{mL})\end{array}$ & $\begin{array}{c}\text { BTS } \\
(\mu \mathrm{g} / \mathrm{mL})\end{array}$ & $\begin{array}{c}\text { ATS } \\
(\mu \mathrm{g} / \mathrm{mL})\end{array}$ & $\begin{array}{c}\text { NVTS } \\
(\mu \mathrm{g} / \mathrm{mL})\end{array}$ & CVTS $(\mu \mathrm{g} / \mathrm{mL})$ \\
\hline Aspergillus flavus & 48 & 96 & 48 & 48 & 24 \\
\hline Aspergillus fumigatus & 24 & 48 & 24 & 24 & 48 \\
\hline Aspergillus niger & 48 & 24 & 24 & 24 & 24 \\
\hline Candida albicans & 12 & 48 & 96 & 48 & 12 \\
\hline Mucor sp. & 24 & 24 & 48 & 24 & 24 \\
\hline
\end{tabular}

\section{Conclusion}

All the synthesized schiff bases and schiff base complexes have been investigated for their antifungal activity. With our synthesized compounds, it is evident that they showed significant antifungal activity against test organisms. Therefore, these compounds may be used as new antifungal drugs after performing further research works with advanced technology.

\section{Acknowledgement}

The authors are thankful to the authorities of the Institute of Biological Science (IBS), University of Rajshahi, Rajshahi-6205, Bangladesh for kindly providing test microorganisms.

\section{References}

Aboul-Fadl T, Mohammed FA, Hassan EA. 2003. Synthesis, antitubercular activity and pharmacokinetic studies of some schiff bases derived from 1- alkylisatin and isonicotinic acid hydrazide (INH). Archives of Pharmacal Research 26, 778-784.

Ali MM, Azad MAK, Jesmin M, Ahsan S, Rahman M, Khanam JA, Islam MN, Shahriar SMS. 2012. In vivo anticancer activity of vanillin semicarbazone. Asian Pacific Journal of Tropical Biomedicine 3, 438-442.

https://dx.doi.org/10.1016\%2FS2221-1691(12)60072-o
Ali MM, Jesmin M, Azad MAK, Islam MK, Zahan R. 2012. Anti-inflammatory and analgesic activity of acetophenone and benzophenone semicarbazones. Asian Pacific Journal of Tropical Biomedicine S2, S1036-S1039.

https://dx.doi.org/10.1016/S2221-1691(12)60357-8

Aravindakshan KK, Nair CGR. 1984. Preparation and Characterization of Vanillin Thiosemicarbaone Complexes with Co (II), Ni (II), Cu (II), Zn (II), Cd (II) and $\mathrm{Hg}$ (II). Proceedings of the Indian Academy of Sciences (Chemical Sciences) 93, 111-115.

Avaji PG, Vinod Kumar CH, Patil SA, Shivananda KN, Nagaraju C. 2009. Synthesis, spectral characterization, in-vitro microbiological evaluation and cytotoxic activities of novel macrocyclic bis hydrazone. European Journal of Medicinal Chemistry, 44(9), 3552-3559.

https://doi.org/10.1016/j.ejmech.2009.03.032

Barton D, Ollis WD. 1979. Comprehensive organic chemistry. Vol. II. Oxford: Pergamon Press, p1031ff.

Chandramouli C, Shivanand MR, Nayanbhai TB, Bheemachari B, Udupi RH. 2012. Synthesis and biological screening of certain new triazole schiff bases and their derivatives bearing substituted benzothiazole moiety. Journal of Chemical and Pharmaceutical Research 4, 1151-1159. 
Chaubey AK, Pandeya SN. 2012. Synthesis \& anticonvulsant activity (Chemo Shock) of schiff and mannich bases of isatin derivatives with 2-amino pyridine (mechanism of action). International Journal of PharmTech Research 4, 590-598.

Chaudhary A, Nidhi B, Gajraj A, Singh RV. 2003. Antifertility, antibacterial, antifungal and percent disease incidence aspects of macrocyclic complexes of $\mathrm{Mn}$ (II). Journal of Inorganic Biochemistry 96, 393-400.

https://doi.org/10.1016/So162-0134(03)00157-o

\section{Chinnasamy RP, Sundararajan R, Govindaraj}

S. 2010. Synthesis, characterization, and analgesic activity of novel schiff base of isatin derivatives. Journal of Advanced Pharmaceutical Technology and Research 1, 342-347.

https://dx.doi.org/10.4103\%2Fo110-5558.72428

Cimerman Z, Miljanic S, Galic N. 2000. Schiff bases derived from aminopyridines as spectrofluorimetric analytical reagents. Croatica Chemica Acta 73, 81-95.

Espinel-Ingroff A, Fothergill A, Peter J, Rinaldi MG, Walsh TJ. 2002. Testing conditions for determination of minimum fungicidal concentrations of new and established antifungal agents for Aspergillus spp.: NCCLS Collaborative Study. Journal of Clinical Microbiology 4o, 32043208.

www.dx.doi.org/10.1128\%2FJCM.40.9.32043208.2002

Glinma B, Gbaguidi FA, Kpoviessi SDS, Fatondji RH, Poupaert J, Accrombessi GC. 2011. Characterization and antiparasitic activity of benzophenone thiosemicarbazones on Trypanosoma brucei brucei. St. Cerc. St. CICBIA 12, 33-40.

Islam MN, Shahriar SMS, Islam MK, Jesmin M, Ali MM, Khanam JA. 2013. Antibacterial activities of some transition metal schiff base complexes. International Letters of Chemistry, Physics and Astronomy 10, 12-20. www.dx.doi.org/10.18052/www.scipress.com/ILCPA.10.12
Joseyphus RS, Nair MS. 2008. Antibacterial and antifungal studies on some schiff base complexes of zinc(II). Mycobiology 36, 93-98.

https://dx.doi.org/10.4489\%2FMYCO.2008.36.2.093

Mahal A, Abu-El-Halawa R, Zabin SA, Ibrahim

M, Al-Refai M, Kaimari T. 2015. Synthesis, characterization and antifungal activity of some metal complexes derived from quinoxaloylhydrazone. World Journal of Organic Chemistry. 3, 1-8.

https://dx.doi.org/10.12691/wjoc-3-1-1

Matar SA, Talib WH, Mustafa MS, Mubarak MS, AlDamen MA. 2015. Synthesis, characterization, and antimicrobial activity of schiff bases derived from benzaldehydes and 3,3'diaminodipropylamine. Arabian Journal of Chemistry 8, $850-857$.

https://doi.org/10.1016/j.arabjc.2012.12.039

Miri R, Razzaghi-asl N, Mohammadi MK. 2013. QM study and conformational analysis of an isatin schiff base as a potential cytotoxic agent. Journal of Molecular Modeling 19, 727-735.

https://dx.doi.org/10.1007/s00894-012-1586-x

Pandeya SN, Sriram D, Nath G, Declercq E. 1999. Synthesis, antibacterial, antifungal and anti HIV activities of schiff and mannich bases derived from isatin derivatives and $\mathrm{N}-\left[4-\left(4^{\prime}\right.\right.$ chlorophenyl) thiazol-2-yl] thiosemicarbazide. European Journal of Pharmaceutical Sciences 9, 25-31.

Quraishi MA, Jamal D, Luqman M. 2002. Corrosion behavior of VTS, STS and DTS inhibitor in formic and acetic acids. Indian Journal of Chemical Technology 9, 479-483.

Sadeh H, Abu Shaireh EA, Mosleh IM, AlBakri AG, Mubarak MS. 2011. Synthesis, characterization and biological activity of schiff bases derived from metronidazole. Medicinal Chemistry Research 21, 2969-2974.

https://doi.org/10.1007/s00044-011-9830-y 
Sathe BS, Jaychandran E, Jagtap VA, Sreenivasa GM. 2011. Synthesis, characterization and anti-inflammatory evaluation of new fluorobenzothiazole schiff's bases. International Journal of Pharmaceutical Research and Development 3, 164-169.

Schiff H. 1864. Mittheilungen aus dem Universitätslaboratorium in Pisa: eine neue reihe organischer Basen. Justus Liebigs Annalen Der Chemie 131, 118-119.

Srivastava OP. 1984. Tech for Evaluation of Antimicrobial Properties of Natural Product, In: The Use of Pharmacological Tech for Evaluation of Natural Products, Edited by Dewn BN and Srinal RC., p75.

Srivastva AN, Singh NP, Shriwastaw CK. 2016. In vitro antibacterial and antifungal activities of binuclear transition metal complexes of ONNO schiff base and 5-methyl-2,6-pyrimidine-dione and their spectroscopic validation. Arabian Journal of Chemistry. 9, 48-61.

https://doi.org/10.1016/j.arabjc.2014.10.004
Vashi K, Naik HB. 2004. Synthesis of novel schiff base and azetidinone derivatives and their antibacterial activity. European Journal of Chemistry 1, 272-275.

http://dx.doi.org/10.1155/2004/158924

Venkatesh P. 2011. Synthesis, characterization and antimicrobial activity of various schiff bases complexes of $\mathrm{Zn}$ (II) and $\mathrm{Cu}$ (II) ions. Asian Journal of Pharmaceutical and Health Sciences 1, 8-11.

Venugopala KN, Jayashree BS. 2003. Synthesis of carboxamides of 2'-amino-4'-(6-bromo-3 coumarinyl) thiazole as analgesic and antiinflammatory agents. Indian Journal of Heterocyclic Chemistry 12, 307-310.

Wei D, Li N, Lu G, Yao K. 2006. Synthesis, catalytic and biological activity of novel dinuclear copper complex with schiff base. Science in China: Series B Chemistry 49, 225-229. https://doi.org/10.1007/s11426-006-0225-8 